\title{
ASSESSMENT OF KINETIC PARAMETERS IN THE WATERS OF THE NISTRU COURSE IN THE SECTION NASLAVCEA - DUBASARI
}

\author{
Elena Bunduchi ${ }^{\mathrm{a}^{*}}$, Gheorghe Duca ${ }^{\mathrm{b}}$, Viorica Gladchi ${ }^{\mathrm{a}}$, Nelli Goreaceva $^{\mathrm{a}}$, Mardari Igor $^{\mathrm{a}}$ \\ ${ }^{a}$ Moldova State University, 60 A.Mateevici str. MD 2009, Moldova \\ ${ }^{b}$ Academy of Sciences of Moldova, Stefan cel Mare 1, Moldova \\ *E-mail: ebunduchi@mail.md,phone: 577796,fax: 577557
}

\begin{abstract}
The current work represents the results of a monitoring executed on Nistru River waters between October 2003 and September 2005. The water quality was evaluated on the basis of such kinetic indicators as redox state and capacity of inhibition. The obtained results shows that Nistru River water in the segment Naslavcea village - Dubasari barrage are continuously polluted with reducing substances that diminish the $\mathrm{H}_{2} \mathrm{O}_{2}$ content, that actually determines the redox state of natural waters and the content of free radicals
\end{abstract}

Keywords: kinetic indicators, hydrogen peroxide, redox state, free radicals, inhibition capacity.

\section{Introduction}

As a system of environmental supervision and control, monitoring is intended to perform a supervision, assessment of the practical environment and the forecasting of eventual changes. The main constituent part of monitoring is environmental assessment.

Aimed at the assessment and control over content of substances in the aquatic medium the existing hydrochemical and hydrobiological methods of monitoring are built upon the principle of comparison of the values observed in the natural medium with the maximum permissible concentrations (MPC). It is not always that these measurements can reflect water quality by criteria that are adequate to its biological value. Therefore, in water quality assessment kinetic indicators and biotesting methods should be a priority, as being integral values that characterize the efficiency of self-purification processes [1]. The quality of environmental water should by stated not only by the content of certain substances in it, but by its biological value. In waters of adequate biological value there are normally carried processes of vital activity and reproduction of biological forms at different trophic levels in such a way that the cycle of chemical substances with the participation of all members of the ecosystem is closed..

The kinetic surface water quality indicators characterize the content and the dynamics of the products of single-electron activation of molecular oxygen, among which there stand up particular redox agents of very high activity: hydroxide radical, singlet oxygen, superoxide anions and hydrogen peroxide. These values and the dynamics of these indicators enable the determination of the degree of quality of the water body, its biological value and selfpurification capacity.

The content of hydrogen peroxide in natural waters is the result of the influence of a number of biotic and abiotic factors that define the dynamic water redox state. From the ecological point of view the water body quality is assessed based on the analysis of the redox state dynamics.

The biologically valuable state of the natural waters is considered to be their oxidative state when hydrogen peroxide is present in concentrations physiologically favorable for aquatic forms, of the order of $10^{-6} \mathrm{~mol} / \mathrm{l}$.

The cycle of hydrogen peroxide in the natural aquatic medium is influenced by the human factor, which often leads to a decrease in the concentration of the substance. The decrease in concentration of hydrogen peroxide in water is caused not only by the discharge of biologically treated waste waters loaded with reductive substances that react with $\mathrm{H}_{2} \mathrm{O}_{2}$ but also by a boost of the green-blue algae that emit toxic reductive metabolites in the outer medium. The discharge of waters containing biogenic elements $(\mathrm{N}$ and $\mathrm{P})$ and water course regulation are the main human factors stimulating the flourishing of the green-blue algae in the natural algae community [2].

The phenomenon of importance of the free radicals in natural waters has become a subject of discussion and study not so long ago. Among the products of monoelectric reduction of the molecular oxygen the $\mathrm{OH}$ radicals tend to have higher oxidative properties. According to the results of investigations from literature sources the permanent concentration of $\mathrm{OH}$ radicals, the strongest oxidant of the natural waters, is very low $\left(\approx 10^{-15}-10^{-17} \mathrm{M}\right)$, that is why at the beginning there were doubts on whether they can have a significant role in the self-purification processes of natural waters. A parameter that characterizes the capacity of natural waters for inhibition of radical self-purification processes with the participation of $O H$ radicals is the inhibition capacity $\left(\Sigma \mathrm{k}_{i}\left[\mathrm{~S}_{i}\right]\right)$ [2]. The value and physical sense of the inhibition capacity enable us to treat it as an effective interruption constant of the radical chain in the processes of oxidation in the natural waters.

According to the capacity of inhibition of self-purification by radicals all natural waters can be classified in three categories:

1) if $\Sigma \mathrm{k}_{\mathrm{i}}\left[\mathrm{S}_{\mathrm{i}}\right]<10^{4} \mathrm{~s}^{-1}-$ the water is considered pure

2) if $\Sigma \mathrm{k}_{\mathrm{i}}\left[\mathrm{S}_{\mathrm{i}}\right] \approx 10^{5} \mathrm{~s}^{-1}$ - the natural water is in normal state

3) $\Sigma \mathrm{k}_{\mathrm{i}}\left[\mathrm{S}_{\mathrm{i}}\right]>10^{6} \mathrm{~s}^{-1}$ - the water is highly polluted

The monitoring of processes with the participation of free radicals in aquatic systems is necessary for both the evaluation of the self-purification capacity and prevention of the appearance of the phenomenon of toxicity for aquatic forms. From the point of view of efficiency of the self-purification processes with the participation of free radicals the 
growth of permanent concentration of the $\mathrm{OH}$ radicals represents a positive factor. However, together with the growth of radical's concentration there appears the threat of involvement in the radical processes not only of pollutants, but also of natural environmental components parts of the biological cycle of substances, as well as of interruption of biogeochemical cycle of manganese ions. The growth of the permanent concentration of the $\mathrm{OH}$ radicals may be a result of either the growth of the initiation rate, or of decrease of the $\mathrm{OH}$ radicals reaction constant through various "traps". The radical initiation rate grows in polluted medium, especially with nitrates and nitrites (particularly during abundant precipitations) or as a result of radioactive pollution.

\section{Results}

The Nistru river represents an important aquatic arteria for the Republic of Moldova at the same time being a source of drinking water and fishery products and playing the role of a valuable recreation zone. Monitoring of the Nistru water quality has always been a priority in the investigations in the Republic of Moldova [3-5]. With the purpose of estimation of the human impact on the Nistru water quality using the classical indicators and the kinetic ones (the content of hydrogen peroxide, redox state, concentration of $\mathrm{OH}$ radicals, the inhibition capacity) many expeditions have been carried out.

In the framework of an expedition along the segment between the Byk river and Dnestrovsk liman (1987), nearly all the samples of water did not show the presence of $\mathrm{H}_{2} \mathrm{O}_{2}$, but only of reductants in concentrations in the range of values $(0.5-120) \cdot 10^{-7} \mathrm{~mol} / \mathrm{l}$. Higher levels of concentrations were observed in points of waste water disposal: the Bic river firth $\left(120 \cdot 10^{-7} \mathrm{~mol} / \mathrm{l}\right)$, the Olanesti tinned food factory $\left(4 \cdot 10^{-7} \mathrm{~mol} / \mathrm{l}\right)$, the Belgorod-Dnestrovsk meet factory [3].

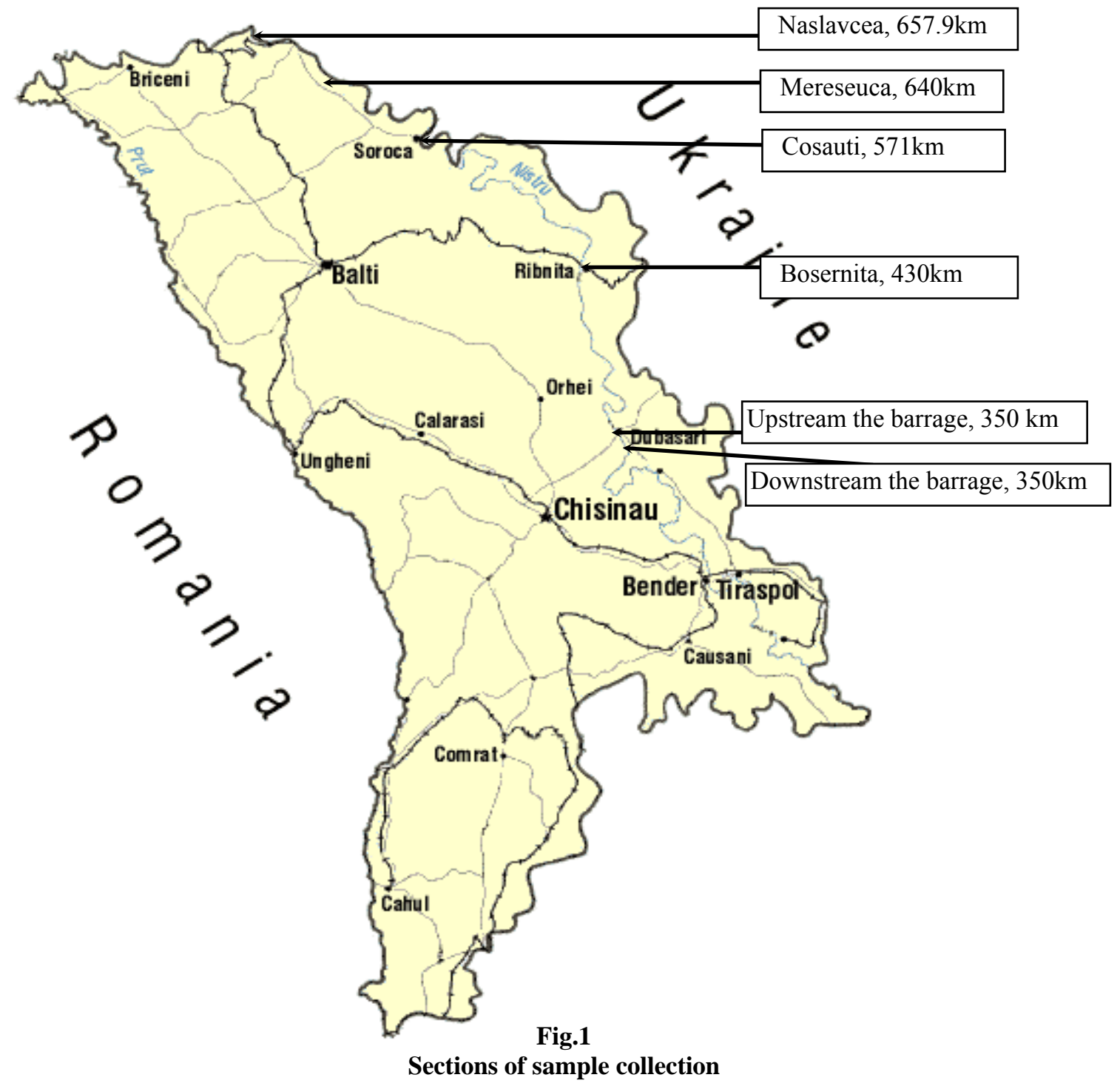

In the framework of another expedition along the Nistru in the segment between the Dubasari dam and the Ciobruciu village (2001) the quality of water was assessed by, alongside with the classical hydrochemical indicators, the $\mathrm{rH}$ indicator. For the whole of the river segment including also some of its effluents (Raut, Ichel, Bic, Botna) the rH values pointed at the domination of reductive processes over the oxidative ones, even in the daytime with a maximum 
solar radiation. A deterioration of the state of waters along this segment was observed especially after the discharge of some quantity of water from the Dubasari water reservoir [4].

The results of the studies performed in the period of 1987 - 2001 characterize the redox state of the waters and the capacity of inhibition in the segment of the river situated downstream the Dubasari dam. That is why we propose to take as an aim the evaluation of the Nistru water state upstream the dam, especially as northward there is another dam, that of the Novodnestrovsc electric power station and the Naslavcea barrage.

With this purpose in April-October 2003 and September-October 2005 there were carried out expeditions along the segment between the village of Naslavcea and the Dubasari barrage. The water samples were taken in the following sections (fig.1): Naslavcea village (200 m around the Naslavcea barrage), Mereşeuca village, Cosăuți village, Boşerniţa village, the Dubasari water reservoir upstream the barrage, $100 \mathrm{~m}$ downstream the Dubasari barrage.

Short characteristics of the sampling sites:

1. v. Naslavcea - cca 50-100 m downstrean the barrage between Ukraine and Moldova.

2. v. Meresheuca - small amounts of green algae, the water flow is considerable.

3. v. Cosauti - on the Ukrainian side there is situated the Iampoli town, 2 ferries are in function there, there is a presence of green algae, the water flow is considerable circulă.

4. v. Boshernitsa -situated 5-10 km upstream the towns of Rezina and Ribnitsa. From here starts the Dubasari water reservoir, there is a presence of considerable number of algae, the water course is smaller than in the first 3 sampling points.

4. Upstream the Dubasari barrage the sample is are collected directly from the barrage, a big number of algae, the water course very low.

5. Downstream the Dubasari barrage the sample is collected about 50-100 m downstream the barrage, the water course varies, depends on the period of collection.

The water samples were collected from the surface layer $(\mathrm{h}=0.5 \mathrm{~m})$. The collected samples were studied for kinetic parameters: the content of hydrofen peroxide and of reductive substances that are oxidized by $\mathrm{H}_{2} \mathrm{O}_{2}$, the dynamics of $\mathrm{H}_{2} \mathrm{O}_{2}$ content and the redox state of the natural waters, the content of free $\mathrm{OH}$ radicals and the selfpurification capacity of the water in the presence of free radicls (the inhibition capacity). The mentioned measurements were done following the methods described in [6]. Besides there were determined the following classical hydrochemical parameters: temperature, $\mathrm{pH}, \mathrm{Eh}, \mathrm{rH}$, electrical conductivity, the main ions that define the mineralization of water, total hardness, the concentration of dissolved oxygen $(\mathrm{DO})$, biochemical oxygen demand $\left(\mathrm{BOD}_{5}\right)$, permanganate value $\left(\mathrm{CCO}_{\mathrm{Mn}}\right)$, chemical oxygen demand $\left(\mathrm{CCO}_{\mathrm{Cr}}\right)$, the concentration of nitrates, nitrites, ammonium nitrogen, phosphates, fluorine, iron, copper, phenols. The measurements were done using a field spectrometer HACH 4010.

Recent data point at the fact that even now there is evidence of variation of the redox state of the Nistru water (tab. 1).

Table 1. The content of hydrogen peroxide and of reductive substances $\left(\left[\mathrm{H}_{2} \mathrm{O}_{2}\right] /\left[\mathrm{DH}_{2}\right]\right)$ in the Nistru water in May-September 2003 and August-December 2005

\begin{tabular}{|l|c|c|c|c|c|c|}
\hline \multirow{2}{*}{ Locality, $k m$ from the firth } & \multicolumn{6}{|c|}{$\left[\mathrm{H}_{2} \mathrm{O}_{2}\right], M /\left[\mathrm{DH}_{2}\right], M$} \\
\cline { 2 - 7 } & $\begin{array}{c}\text { May } \\
2003\end{array}$ & $\begin{array}{c}\text { July } \\
2003\end{array}$ & $\begin{array}{c}\text { September } \\
2003\end{array}$ & $\begin{array}{c}\text { September } \\
2005\end{array}$ & $\begin{array}{c}\text { October } \\
2005\end{array}$ & $\begin{array}{c}\text { November } \\
2005\end{array}$ \\
\hline Naslavcea, 657,9 km & $3.5 \cdot 10^{-7} / 0.0$ & $0.0 / 3.1 \cdot 10^{-7}$ & $0.0 / 4.1 \cdot 10^{-7}$ & $0.0 / 1.1 \cdot 10^{-7}$ & $1.2 \cdot 10^{-6} / 0.0$ & $3.2 \cdot 10^{-7} / 0.0$ \\
\hline Meresheuca, $640 \mathrm{~km}$ & $4.0 \cdot 10^{-7} / 0.0$ & $0.0 / 7.2 \cdot 10^{-7}$ & $0.0 / 3.6 \cdot 10^{-7}$ & $1.2 \cdot 10^{-6} / 0.0$ & $1.1 \cdot 10^{-6} / 0.0$ & $3.5 \cdot 10^{-7} / 0.0$ \\
\hline Cosautsi, 571 km & $3.1 \cdot 10^{-7} / 0.0$ & $0.0 / 6.2 \cdot 10^{-7}$ & $0.0 / 3.8 \cdot 10^{-7}$ & $1.8 \cdot 10^{-6} / 0.0$ & $1.9 \cdot 10^{-6} / 0.0$ & $7.0 \cdot 10^{-7} / 0.0$ \\
\hline Boshernitsa, 430 km & $4.5 \cdot 10^{-7} / 0.0$ & $0.0 / 3.8 \cdot 10^{-7}$ & $0.0 / 3.0 \cdot 10^{-7}$ & $1.4 \cdot 10^{-6} / 0.0$ & $0.0 / 0.0$ & $0.0 / 0.0$ \\
\hline $\begin{array}{l}\text { Upstream the Dubasari } \\
\text { barrage, 350 km }\end{array}$ & - & - & $3.2 \cdot 10^{-7} / 0.0$ & $9.5 \cdot 10^{-6} / 0.0$ & $1.5 \cdot 10^{-6} / 0.0$ & $3.3 \cdot 10^{-7} / 0.0$ \\
\hline $\begin{array}{l}\text { Downstrean the Dubasari } \\
\text { barrage, 350 km }\end{array}$ & - & $0.0 / 3.4 \cdot 10^{-7}$ & $0.0 / 3.4 \cdot 10^{-7}$ & $8.5 \cdot 10^{-6} / 0.0$ & $0.0 / 0.0$ & $4.2 \cdot 10^{-7} / 0.0$ \\
\hline
\end{tabular}

Thus in May 2003 along the mentioned segment the state of waters was characterized as instable oxidative, the samples did not contain reductive substances of peroxide nature, whereas the content of $\mathrm{H}_{2} \mathrm{O}_{2}$ was lower than the physically required $-(3.5-4.5) \cdot 10^{-7} \mathrm{~mol} / \mathrm{l}$. In July and September the same year the collected samples there was no hydrogen peroxide observed, but they showed a content of reductive substances $\left(3 \cdot 10^{-7}-4 \cdot 10^{-7}\right.$ mol/1) which take oxidation by $\mathrm{H}_{2} \mathrm{O}_{2}$ more effectively than by molecular oxygen the concentration of which remained within the 
admissible limits. The results show that towards the end of July the water is in the reductive state, staying at the same level until September inclusively. Similar analysis, performed in the period of August-November 2005, showed that along almost the whole monitored segment, with some exceptions, the waters were in the oxidative state. In September the sample collected near the village of Naslavcea did not contain $\mathrm{H}_{2} \mathrm{O}_{2}$, with a concentration of reductants being of the order of $1,1 \cdot 10^{-7} \mathrm{~mol} / \mathrm{l}$. The reductive state of the waters observed downstream the barrage of Naslavcea may be a result of disequilibrium in the water reservoir upstream the barrage caused by the penetration of big quantities of reductive substances of peroxidase nature. The negative impact of the disequilibrium kept abating along the analized segment because beginning with the collection section v. Meresheuca in the samples there was observed a presence of hydrogen peroxide in the range of values $1,2 \cdot 10^{-6}-8,5 \cdot 10^{-6} \mathrm{~mol} / \mathrm{l}$. In October-November the analysis of samples collected near the location of Boshernitsa and downstrean the Dubasari barrage (October) points at the formation of an instable state which is characterized by the absence in the samples of either hydrogen peroxide or reductive substances of peroxidase nature.

The evaluation of waters according to the capacity of inhibition indicator gave the results presented below.

In October 2005 the inhibition capacity values in the Nistru waters pointed at a normal course of free radical self-purification processes $\left(2,95 \cdot 10^{5}-8,02 \cdot 10^{5} \mathrm{~s}^{-1}\right)$, with the exception of the Cosautsi collection site $\left(1,31 \cdot 10^{6} \mathrm{~s}^{-1}\right)$ and downstream the Dubasari barrage $\left(2,31 \cdot 10^{6} \mathrm{~s}^{-1}\right)$. In November there was evidence of the same unfavorable situation in self-purification in the region of the Cosautsi village $\left(1,24 \cdot 10^{6} \mathrm{~s}^{-1}\right)$ and downstream the Dubasari barrage $\left(1,40 \cdot 10^{6} \mathrm{~s}^{-1}\right)$, demonstrating a deviation from the normal course of radical self-purification processes, including the Naslavcea point $\left(1,30 \cdot 10^{6} \mathrm{~s}^{-1}\right)$. Through the obtained inhibition capacity values the waters can be characterized as being in a normal state in the studied segment (order of $10^{5} \mathrm{~s}^{-1}$ ) with the exception of the v. Naslavcea, v. Cosautsi points and downstream the Dubasari barrage (order of $10^{6} \mathrm{~s}^{-1}$ ).

\section{Conclusions}

The content of waters depends on both the natural climatic conditions and on the regime of operation of various hydrotechnical sites, and respectively on the volume and the composition of the incoming water and that going out downstream the barrage and hydro stations. The Nistru waters that find their way to the territory of Ukraine are polluted with organic substances that disturb the redox components' equilibrium in the section of the village Naslavcea. The deterioration of the Nistru water quality is based on the degree of pollution of the effluents and waste waters discharged from the riverain localities. From the said above results the importance of continuous monitoring of the Nistru water quality, especially through integral kinetic indicators.

The results showed that the Nistru waters remain to be polluted with reductive substances that reduce the content of hydrogen peroxide in the water body and inhibit the autopurification processes with free radicals participation, creating conditions for the formation of the reductive state in water ecosystems - an unfavorable state for aquatic forms.

It is important that the analysis of kinetic parameters and the classical hydrochemical ones did not show any correlation between them. In case of the change of the redox state of the natural waters from oxidative to reductive as well as the identification of unsatisfactory capacity of inhibition, the hydrochemical indicators correspond to those in the normal state of the waters. This is why the concentration of hydrogen peroxide, redox state, the concentration of $\mathrm{OH}$ radicals and the capacity of inhibition have to be considered the fundamental indicators in the assessment of the quality of natural waters.

\section{References}

[1] Скурлатов Ю.И., Дука Г.Г., Штамм Е.В. Введение в экологическую химию водной среды. Воок of proceedings Ecological chemistry, Third International Conference, May 20-21, 2005, p. 78-85

[2] Скурлатов Ю.И., Дука Г.Г., Эрнестова Л.С., Процессы токсикации и механизмы самоочищения природной воды в условиях антропогенных воздействий// Изв. АН МССР «Серия «Биологические и химические науки»»».-1983.-№5.-стр. 3-20

[3] Романчук Л.С. Окислительно-восстановительный катализ и фотолиз некоторых оксо- и оксикислот // Дисс. канд. хим. наук.- Кишинёв, 1990.-165 с. (с.105-107)

[4] Бородаев Р. Редокс условия нижнего Днестра и состояние растворённых форм железа и меди // Analele ştiinţifice ale Universității de Stat din Moldova, Seria „Ştiințe chimico-biologice” .-2002 .-p.401-407

[5] Duca Gh., Goreaceva N., Romanciuc L., Gladchi V. Starea ecologică a apelor de suprafață în Republica Moldova // Intellectus.-1999.-nr.4.-p.62-68

[6] Руководящий документ. Методические указания. Методика определения кинетических показателей качества поверхностных (пресных вод). Москва: Гидрометеоиздат, 1990, 36 с. 